\title{
Chapter 8 \\ Natural Disasters in the History of the Eastern Turk Empire
}

\author{
Rustam Talgatovich Ganiev and Vladimir Vladimirovich Kukarskih
}

\begin{abstract}
This article analyzes the effect of climate extremes on the historical processes that took place (AD 536, 581, 601, 626 and 679) in the Eastern Turk Empire (AD 534-745) in Inner Asia. Climate extremes are sharp, strong and sometimes protracted periods of cooling and drought caused by volcanic eruptions that in this case resulted in a negative effect on the economy of a nomadic society and were often accompanied by famine and illness. In fact, many of these natural catastrophes coincided with the Black Death pandemics among the Eastern Turks and the Chinese living in the north of China. The Turk Empire can be split into several chronological periods during which significant events that led to changes in the course of history of the nomadic state took place: AD 534-545-the rise of the Turk Empire; AD 581-583 - the division of the Turk Empire into the Western and the Eastern Empires; AD 601-603 - the rise of Qimin Qaghan; AD 627-630 - the Eastern Turks are conquered by China; AD 679-687-the second rise of the Eastern Turk Empire. The research shows that there is clearly-discernable interplay between important historical events and climate extremes in the history of the Turk Empire. This interplay has led us to the conclusion that the climatic factor did have an impact on the historical processes that took place in the eastern part of Inner Asia, especially on the territories with a nomadic economy.
\end{abstract}

Keywords Turks (Tujue) - The Eastern Turk Empire $\cdot$ China $\cdot$ Climatic change Dendrochronology $\cdot$ Ice-core

\footnotetext{
R. T. Ganiev (凶)

Department of History of the Institute of Humanities and Arts, Ural Federal University Named After the First President of Russia Boris Yeltsin, 51 Lenin St., Yekaterinburg 620000, Russian Federation e-mail: rusthist@yandex.ru

V. V. Kukarskih

Institute of Plant and Animal Ecology, Ural Branch of the Russian Academy of Sciences, 202/3 8 Marta St., Yekaterinburg 620144, Russian Federation

e-mail: voloduke@mail.ru

(C) The Author(s) 2019

L. E. Yang et al. (eds.), Socio-Environmental Dynamics along the Historical Silk Road, https://doi.org/10.1007/978-3-030-00728-7_8
} 


\subsection{Introduction}

The middle of the 6th century saw the rise of a new nomadic Turk Empire on the territory of what today is Mongolia and Southern Siberia. In a period of 20 years (AD 551-573), as a result of active military campaigns, the Turks (Tujue) spread their influence onto a vast territory of Inner Asia that ranged from the Caspian Sea to Liaodong Bay. As a result, a vast number of non-Turkic peoples found themselves included into their empire. The Turks played a significant role in the cultural interaction of the West and the East. They furthered the development of trade along the Great Silk Road and established trade relations with the leading empires of the time (Sasanian Empire, Byzantium and China). In AD 581, the Turk Empire broke up into two parts - the Western one and the Eastern one. We are going to dwell mainly on the Eastern Turk Empire. Its northern borders spread out to Lake Baikal, the southern to North China (the Great Wall), the western to Eastern Kazakhstan, including Tuva and the Altai, the eastern to the Greater Khingan Range (Fig. 8.1).

Researchers divide the history of the Turk Empire into several periods (Sinor 1990b; Barfield 1992; Gumilev 1967; Klyashtorny 1964; Beckwith 2009). The first (AD 534-630) is characterized by the appearance of the Turks on the Chinese border and the beginning of intensive Turkic-Chinese trade relations accompanied by a gradual strengthening and broadening of the spheres of influence of the nomadic state. In the second period (AD 630-679) the independent state of the Turks was non-existent anymore. The main reason for the defeat of the Turks is considered to be the military campaign undertaken by Emperor Taizong in AD 630 which was later followed by his active policy in strengthening China in AD 630-649. The consequence of this was that the Turks were no longer a serious military or political threat until the year

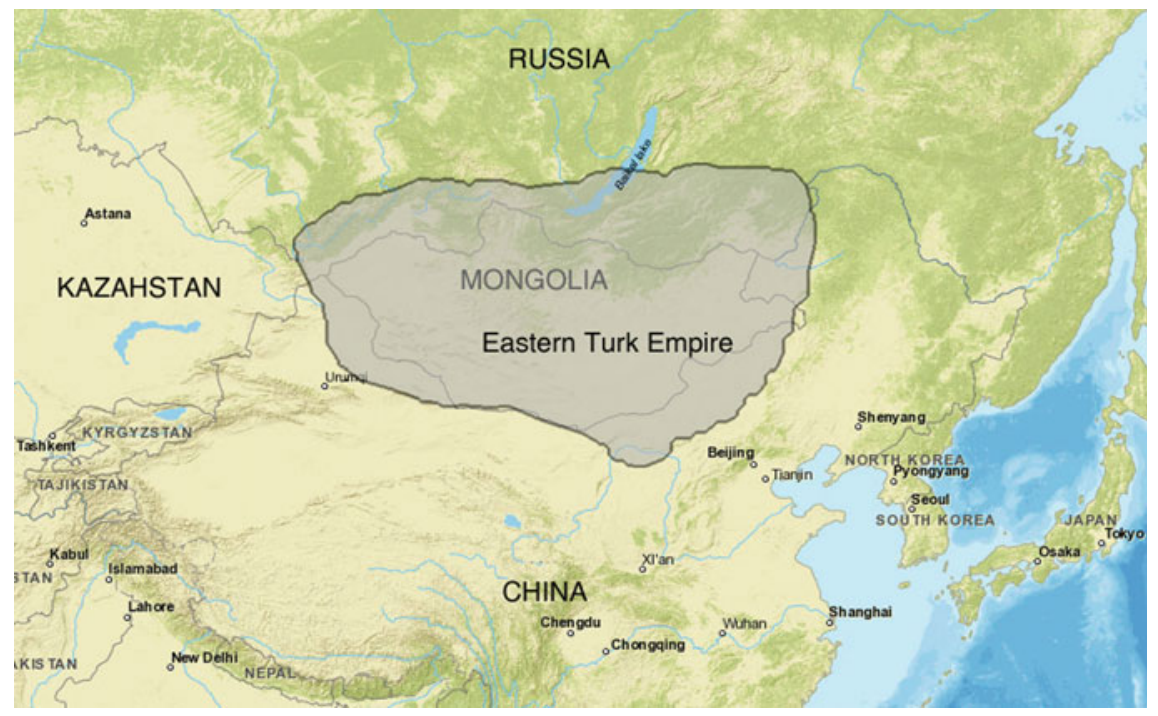

Fig. 8.1 Map of the Eastern Turk Empire 
AD 679 when several uprisings occurred. The third and last period (AD 679-745) is characterized by the rise of the Eastern Turk Empire, which managed to restore itself by undertaking several massive rebellions against the Chinese army in AD 679-685.

The Turk Empire continued to be China's main rival up to AD 745, that is, until the time when the Uyghur Empire conquered both of them (AD 745-840) (Mackerras 2000; Kamalov 2001). Therefore, the history of the Turk Empire consists of several chronological stages during which periods important historical events took place: AD 534-545-the strengthening and appearance of the Turks on the international arena; AD 581-583 - the division of the Turk Empire into its Western and Eastern parts; AD 601-603 - the weakening of the Western Turks and the strengthening the Eastern Turks under the leadership of Qimin Qaghan; AD 627-630 - the maximum weakening and subordination of the Turks to China; AD 679-685-the rebirth and consequent strengthening of the Turk Empire.

Sinologists and turkologists have been trying to find reasons why all these events took place mainly by analyzing the regularity of development of socio-economic, military and political laws of the nomadic society and of China in Inner Asia (Kradin 2014; Beckwith 2009). However, historians have practically never taken into consideration the effect produced by natural and climatic factors in the region under study. The aim of this research is to show the importance of climatic cataclysms that occurred in Inner Asia during the period under consideration and the effect they had on the key historical events in the Turk Empire.

\subsection{Methods}

Changes in climate and their effect on human society is one of the most pressing problems for the world today and for science in particular (Fei et al. 2004; Zhang et al. 2007, 2010; Büntgen et al. 2011; Zhang et al. 2011; Ludlow et al. 2013; Hsiang et al. 2013; Wei et al. 2015). Global warming and human susceptibility to it cannot be taken lightly (Trenberth 2012).

In the recent period quite a number of works (Pederson et al. 2014; Büntgen et al. 2016; Di Cosmo et al. 2017; Putnam et al. 2016; Drobyshev 2014) have been devoted to the problem of the influence of changes in climate on the culture of whole nations, those living in Inner Asia being among them. A number of researchers hold to the opinion that climate changes could have led to grave consequences for the nomadic peoples if they were accompanied by unfavorable socio-political and economic factors. In other words, climate extremes may have a negative influence only if they coincide with unfavorable socio-economic, political and demographic changes within the nomadic society (Di Cosmo et al. 2017). This work is devoted to the influence of climate dynamics on the history of the Eastern Turk Empire. Our research shows that in several cases changes in climate could, in fact, have exerted a crucial influence on the political and economic life of the Turks.

Medieval economy operated in a traditional way and was to a greater degree than now dependent on climatic factors. One of the regions that were highly exposed to natural cataclysms in the early Middle Ages was that of Inner Asia and the nomads who lived there. 
Though nomadic societies were highly mobile, large-scale changes in ecological factors (mainly climatic) must have, no doubt, told on the livestock that was the basis of nomadic culture (Sinor 1990a, b). This makes it possible for us to say that longterm temperature fluctuations and climate extremes in particular did have a global effect. Evidence of this can be found in the registered yearly tree-ring structures in all parts of the Northern Hemisphere.

It is also known that in the period of climate extremes the nomads practiced a mutually agreed-upon consecutive grazing of cattle or changed their regional location by moving along the steppes. However, in quite a number of cases, the Turks could not do this for the reason that the relations with their neighbors were not friendly at all, there being a fierce competitive struggle between the rival tribes for the bordering territories.

Our research is based on tree-ring data (D'Arrigo et al. 2001; Hantemirov et al. 2011; Myglan et al. 2012; Briffa et al. 2013) which makes it possible to determine climate extremes to a higher degree of accuracy than the more general chronological results ice-core study gives (Clausen et al. 1997; Cole-Dai et al. 2000; Jiang et al. 2012; Plummer et al. 2012; Jouzel 2013; Abbott et al. 2014). With the help of documentary sources, we shall compare the political and socio-economic evidence of events that took place in the Turk Empire with the material received from contemporary climatological research.

Unfortunately, climate reconstructions for the period under examination are too short-term and inadequate as far as their quality is concerned (https://www.ncdc. noaa.gov/data-access/paleoclimatology-data/datasets). Global atmospheric circulations, mainly the NOA (North Atlantic Oscillation) and the AO (Arctic Oscillation) make it possible for us to refer to distant paleo-climatological sources to help understand the processes that took place on the territory of the Turk Empire. Similar teleconnections were described earlier in other works (Büntgen et al. 2016), that is why we have analyzed oscillatory reconstructions for the Northern Hemisphere taken from other regions. Most of the information on the history of the Turk Empire is based on Chinese dynastic chronicles-Zhoushu, Beiqishu, Suishu, Jiutangshu and Xintangshu (Bichurin 1828, 1950; Liu 1958; Cen 1958; Ershisi shi 2012).

\subsection{The Influence of Climate Extremes on the History of the Eastern Turk Empire in AD 536-685}

\subsubsection{Climate Extremes of AD 536-545}

Turkic tribes are first mentioned in Chinese chronicles of AD 534 (Liu 1958), which describe the appearance of the Turks on the border with China as buyers of Chinese goods, but not as typical barbarians whose aim is to raid, as is often depicted in Chinese sources. 
The Turks are next mentioned in the sources of AD 542. Only 8 years had passed between AD 534 and 542, but modern climatologists tell us that these 8 years were the ones with the greatest climatic changes in the history of the medieval world. A sharp fall in the mean temperature took place in the Northern Hemisphere, one of the worst in the last 2000 years (Keys 2000).

Here is what the famous Byzantine historian, Procopius of Caesaria, wrote about the events of AD 536-537: "One of the greatest wonders took place that year: the whole year the sun shone like the moon, without rays, as if it was going to lose its power. It did not shine clearly and brightly as before. Ever since then, there were wars among people, pestilence and other calamities that brought death with them" (Procopius 1998).

In AD 536-537, similar phenomena were noted in other regions: Ireland, China, Chile, Europe and Asia (Barash 1989). The Anglo-Saxon Chronicle in Britain also says: "AD 538. This year the sun was eclipsed, fourteen days before the calends of March, from before morning until nine. A.D. 540. This year the sun was eclipsed on the twelfth day before the calends of July; and the stars showed themselves full nigh half an hour over nine" (Garmonsway 1972).

Today, the climatic anomalies of AD 536-545 have brought together a great number of scientists who are studying this problem. Participants of The Greenland Ice Sheet Project (GISP) have studied samples of ice core from Greenland and the Antarctic (Jouzel 2013). They have discovered that ice samples of AD 536, 538, 539, 541 and 543 from Greenland all have a very high content of sulfates (Baillie 2008; Abbott et al. 2014), which may point to their high content in the atmosphere at that time and to the low temperatures of their formation (Larsen et al. 2008).

Dendrochronological data also indicate that the years AD 536, 537, 543 and 545 were the ones with the coldest extremes (D'Arrigo et al. 2001; Hantemirov et al. 2011; Myglan et al. 2012).

Volcanologists study samples of lava and traces of past explosive volcanic eruptions. They analyze the chemical composition of mineral ores and the activity of volcanoes. Several volcanologists adhere to the opinion that the reason for such a temperature drop in AD 536-545 could have been the eruption of Krakatau on the Philippines or Tavurvur in Papua New Guinea (Keys 2000; Southon et al. 2013; Churakova-Sidorova et al. 2014).

Other scientists think that the reason for the anomaly could have been a comet or an asteroid that hit the Earth (Rigby et al. 2004), but here arises the question of where exactly it had happened. Dr. Dallas Abbott says that the Gulf of Carpentaria in the north of Australia could have been one of the locations (Abbott et al. 2007).

Currently Dr. Dallas Abbott is working on a hypothesis that volcanic and cosmic reasons had caused the climate extremes of AD 536-545 (Abbott et al. 2014). Dr. Abbott thinks that it was the dramatic events of AD 536-545 that produced an overall cooling effect on the planet (in the Northern Hemisphere). Researchers have found traces of volcanic activity in Greenland ice cores, but a single eruption in AD 536 would not have caused such an extreme change in climate. Dr. Dallas Abbott believes that there might have been a volcanic eruption along with a comet, but the main factor was, most probably, a comet strike. As proof of this, samples of Greenland ice have 
shown contents of alien particles with Ni-rich material and Fe oxide-rich spherules, both of which are the characteristic signs of cosmic objects (Abbott et al. 2014).

The overall effects of cooling led to the great disasters that took place in the Middle Ages. Moreover, a pandemic called the Plague of Justinian (Stavrakakis 2015) struck at the very same time. It is the first historically known pandemic of the Black Death and it is remembered in history as the plague of the Byzantine Emperor Justinian I. More than 100 million people perished as a result. The Plague of Justinian originated in Egypt in AD 540-541. Then it was brought by Mediterranean trade routes to Constantinople, from there to all of Byzantium, then to the countries of North Africa, Europe, Central and South Asia and Arabia. However, the latest genetic studies show that the Plague of Justinian did not come from Africa-it came from Inner Asia (Wagner et al. 2014; Schmid et al. 2015). Rodents, such as marmots, gophers, rats and mice are the natural reservoirs of the plague, and consequently myriads of fleas, which live on rodents, are the carriers of the disease.

It is not accidental that after AD 534 Chinese sources do not mention any contacts with the Turks until AD 545. One of the possible reasons for this may be the decline in economic production and the decrease of population both in China and in the Turk Empire. In addition to that, in the years AD 534-535, a civil war broke out in China, the result of which was the division of the Northern Wei Dynasty into the Eastern Wei Dynasty and the Western Wei Dynasty. Moreover, in the years AD 536-537, North China was hit by a famine that killed $80 \%$ of its population (Bichurin 1828; Durand 1960).

Unfortunately, written sources say nothing of the plagues that affected the Turks in that period, but taking into account the plague pandemic in the east of North China and in the west of Byzantium, the Turks, who were located along the trading routes of the Great Silk Road, must have also suffered from the disease. As is known, prior to AD 630, that is before they began to have active relations with China, the Turks did not bury their dead, they cremated them. This might be the reason why, in the period from 543 to 551, the Turks were able not only to withstand all of nature's trials, but emerge from them with minimal losses. The fact that the density of population at the start of the formation of the powerful and huge Turk Empire was not too great could serve as an additional factor that helped them to survive. To note, the density of population in North China at the time was considerable.

Let's look at the main events of that period.

In $\mathrm{AD}$ 534-545, there were four strongholds in the region: the Eastern Wei Dynasty, the Western Wei Dynasty, the Rouran Empire, and the recently formed Turk Empire that had conquered the Rouran Empire, but remained in the shade, though it had already made itself known to the Chinese in AD 534 as a new and independent political force (Liu 1958).

Both dynasties (the Western Wei and the Eastern Wei) rivaled with each other to establish friendly contacts with the Rouran Empire by way of a marriage union. The struggle went on against the background of climatic anomalies and, as a result, there was economic decline, so it can be well supposed that the Chinese had lost their former strength. The Rouran took advantage of the situation in China, but did not take into account the internal situation in its own Empire. The Western Wei Dynasty 
turned to the Turks for help. Thus, in AD 545, a new center of political and military power appeared in the region, one in which the Turks began to play the leading role (Liu 1958).

A new stage in the rise of the Turks was their victory over the Tiele tribe in AD 546. The Tiele were a threat to the dominance of the Rouran and the Turks took upon themselves the task of protecting them. The final mistake that the Rouran Empire made was their refusal to agree to a matrimonial union with the Turks, thus making relations between them hostile. After that, it took the Turks seven years to overcome the climate extremes of AD 536-545, though later, in AD 552, they came to occupy the place of suzerain in the region.

This shows that the climatic extremes of AD 534-545 were the catalyst that aggravated the internal and external political struggle between the Chinese dynasties, a factor which led to a more serious situation than the one the nomads in the steppes were in. The internal political strife in China in AD 534-535 and the anomalies of AD 536-545 that aggravated China's situation were the main reasons that led to changes in the military and political affairs in the region. China lost its strength when, in tough competition with the Tiele and the Rouran, the Turk Empire gained power. The Turks were more successful due to the timely mobilization of their internal forces and the excellent personal skills of their leaders.

\subsubsection{Climate Extremes of AD 581-583}

The united Turk Empire was not long in existence. After the death of the Turkic leader Taspar (Tobo) Qaghan in AD 581, internal strife began to ferment within the ruling circles of the Empire which in the end led to its collapse. In addition to that, in AD 581, China, being already split prior to that, joined forces under the Sui Dynasty (AD 581-618). The reforms that took place in China led to the fast growth of the economic and military strength of the Empire. Chinese sources inform us that China's rise was accompanied by a most devastating famine in the steppes (Bichurin 1950).

The Suishu chronicle writes: "Each winter they have thunder there, and the flames of the lightning hit the Earth. The Tujue's life depends on grass and water. All throughout the previous year there was no rain, no snow, their rivers have dried up and locusts have appeared; plants and trees have been totally destroyed by fire; half the population has died of hunger and disease. The place where they used to live before has become wasteland not fit for living. So they turned their steps to the south of the desert to try and brave it out ... They suffered from famine, and couldn't find food for themselves, so they grinded bones to make flour out of them-and that's what they ate. Moreover, an epidemic broke out, and many of them died (Liu 1958).

Unfortunately, Chinese sources do not contain more detailed information about the events of that period. But it can be understood that the climatic anomaly and its effects on the common people of the Turk Empire, who were deprived of their means of existence as a result of massive livestock loss in AD 581-583, brought the Turk 
Empire to a sudden social and political crisis and internal warfare, the result being that the Turk Empire finally split into the Eastern Empire and the Western Empire.

Natural anomalies of AD 581-583 have been confirmed by ice-core finds in the Antarctic and in Greenland and also by tree-ring data from North America and Southern Siberia (Clausen et al. 1997; Cole-Dai et al. 2000; Salzer and Hughes 2007; Gao et al. 2008; Jiang et al. 2012; Myglan et al. 2012; Plummer et al. 2012; Sigl et al. 2013, 2015). The studies of climatic extremes range from the years AD 564 to 581 . The clearer evidence comes from ice cores of the Southern Hemisphere, which makes it possible to confirm that the volcano was located somewhere in that part of the planet. However, we shall be able to get a fuller picture of natural extremes of AD 581-583 only after additional research.

\subsubsection{Climatic Extremes of AD 599-601}

After the collapse of the Turk Empire (AD 581-583), the Western and the Eastern Turks were in a state of constant warfare with each other. The Sui Dynasty was originally a neutral party in the conflict, but soon the Chinese set up and supported a new political center in the southern part of the Eastern Turk Empire with Qimin Qaghan as their new leader. The new Turk Empire, supported by the Sui Dynasty, undertook a confrontation with the Eastern and the Western Turks, both of them uniting against it in the warfare that followed. However, in AD 603, Qimin Qaghan defeated them and united the whole territory of the Eastern Turk Empire under his command. It is obvious that climate extremes played a significant role in the glorious victory and tremendous success of the young Qaghan. In AD 598-599, sources report about natural climatic events that were mistakenly taken for two large military campaigns of Emperor Wen of the Sui dynasty against the Eastern Turks (Tulan Qaghan) "frequent disasters occur over their camps; a red rainbow in the night, its light illuminating hundreds of miles all around; three days ... there was a bloody rain, the falling stars with a crash landing on the tents. Every night Tulan Qaghan was in fear, and imagined that it was the Sui army approaching!". In AD 601 , the sources also report an interesting natural phenomenon that turned out to be a major volcanic eruption. A Chinese military commander reported to the Emperor: "When at night I went up onto the fortress tower, I saw a red mist 30 miles north of the desert; it looked like rain, it was hanging low over the land covering it. After that, I found a war guide book where it says that such a phenomenon is called "bloody rain", which means that the country is doomed! If we want to destroy the barbarians, now is the time!" (Liu 1958).

\subsubsection{Climatic Extremes of AD 627-630}

The next period of sharp unseasonal and protracted cooling that affected the Eastern Turks were the years AD 627-630. 
The years AD 627-630 were marked by natural cataclysms on the territory of the Empire. Chinese sources give the following descriptions: "Every year they had heavy snowfalls and snow lay thick on the ground. The cold and the famine brought with it a great loss of sheep, horses and men" (Liu 1958).

The Chinese chronicle Xintangshu says: "In spite of it being summer, the Tujue are having unseasonal frosts; five suns have risen at the same time, three moons shone as well; a red mist covered their pastures" (Liu 1958). This is what the Jiutangshu chronicle says about the situation of the Turks in AD 630: "The Tujue's life depends only on sheep and horses. Now their animals are sick and lean and their people look starved. Besides, when they prepare their food in the tents it turns into blood. This is a dangerous foreboding!" (Liu 1958).

Scientists say that the large-scale cooling on the territory of Eurasia in AD 627-630, evidence of which can be seen on tree-rings in Yamal, in North America and in the north of Central and Eastern Siberia, was caused by large explosive volcanic eruptions (Stothers 1999) and the parhelion. Fog and red sunsets described in the sources are well-known indicators of such eruptions. We know from European chronicles that, starting from October AD 626, for about 8 or 9 months, a dry mist covered a vast territory including Ireland and the eastern Mediterranean (Ludlow et al. 2013). Unseasonal night frosts at the end of summer occurred in China (the Tang Empire) in AD 627, which destroyed the harvest in several provinces. Similar events occurred in China in AD 628-629 (Fei et al. 2007).

Economic hardships led to a destabilization of the political situation within the Empire. In AD 627, the conquered tribes rebelled against the Turks and deposed the henchman of the Turkic leader on their territory. Within the Empire, relations between the Ruler and his subjects also became strained. Sources say that the relations between the Qaghan and his closest assistant were severed, the result being that the high official deserted to join the forces of the Chinese Emperor Taizong.

The economic situation put the Turks on the brink of survival and bared all the internal contradictions within their community, the same thing happening in the Eastern Turk Empire.

Sources say: "Xielikehan mobilized soldiers every year and invaded Chinese territory so often that his people could not put up with these campaigns any longer. There was famine year after year. Taxes and payments were heavy, so more and more tribes left him" (Liu 1958). Thus, an internal conflict began to grow within Turkic society; discontent grew, nobody trusted Xielikehan anymore, nor supported the policy he pursued.

The situation in the Empire became worse and many tribes, as the Chinese chroniclers say, began to rely only upon themselves and refused to be under the command of Xielikehan. Even the high officials closest to Xielikehan defected to Taizong. In AD 630, the Emperor's army attacked Xielikehan. As a result, the latter fled to the north of the desert whereas his closest courtiers, the ones who held high posts in the Empire, left him and joined the Tang Dynasty (Liu 1958).

Therefore, the defeat of Xielikehan's army in AD 630 by Chinese forces was a logical solution to the situation that had formed within the Turkic community with the climate extreme of AD 626 being the key to victory and not at all the skillful 
leadership of the Chinese Emperor Taizong of the Tang Dynasty, as many researchers might think.

Chinese researchers who studied the volcanic eruption of AD 626 hold a similar opinion. They believe that the cooling affected all the territory of Inner Asia, as well as the northern provinces of China, but the territory that suffered the most was the Eastern Turk Empire, whose nomadic economy could not withstand the sharp and protracted cooling (Fei et al. 2007; Di Cosmo et al. 2017). In conditions of an economic catastrophe which had put the Turks on the brink of survival, all internal conflicts came to the fore and the powers-that-be could not cope with the situation.

\subsubsection{Climatic Extremes of AD 679-685}

Several decades later, in the years AD 679-685, as a result of a number of rebellions, the Eastern Turk Empire restored its independence and managed to retain it till AD 745. However, the conditions that developed in AD 679-685, as they are described in Chinese sources, also point to a complicated natural and climatic situation in the region.

The Xintangshu chronicle describes a curious event witnessed by Chinese officials on the northern border of China. In the spring of AD 680 large flocks of desert pigeons fell dead from the sky (Liu 1958).

What could have been the reason for such an unusual natural phenomenon described in the Chinese sources? It is well-known that birds are indicators of the state the environment is in. The reason for this could have been both the global changes in the environment and the high content of volcanic dust in the layers of the atmosphere deposited there after a large explosive volcanic eruption.

In addition to that, in the years AD 681-682, Chinese sources repeatedly mention cases of famine among the Eastern Turks. "Famine, snow, drought, locusts, disease, numerous dead bodies lying all around, people turning into cannibals, several years of crop failure and starvation" (Bichurin 1828).

In AD 685, the Chinese official Ts'ui Zhi-zhi in his report to the Chinese Emperor described the situation the nomads were in thus: "The Tujue ... devour each other; they wander around, starved, and don't know where to go".

"Their numbers had already exceeded several tens of thousands of people. They were covered with a rash and had tumors, they were famished and did not resemble human beings at all; countless numbers of people died on the way. Prior to that, the Nine Tribes (Toquz Oghuz) (those who inhabited the area to the north of the Great Chinese Wall) experienced a great drought that lasted for 3 years: all the pastures are reddish with practically no grass growing on them, thus causing massive loss of livestock. Those who came here are those who survived and were able to cross the desert, but on the way here they lost their sheep and horses due to lack of food and water. They had to hunt for field rats and eat the roots of grass; they killed each other to get provision. I asked different people about it and all told me the same story. By the way, one of their old men told me that from the time the Nine Tribes (Toquz 
Oghuz) had come into existence, they had never experienced such a famine..." (Liu 1958).

There is also mention of "The Great Famine" in China in AD 687 (Bichurin 1828). Thus, Chinese chronicles state that many nomads were on the brink of death because of the heavy and protracted famine and disease in AD 682-687, though climate extremes were already mentioned in AD 680-681.

In AD 685, the Anglo-Saxon Chronicle in Britain also mentions climatic anomalies and their consequences: "A.D. 685. This year in Britain there was a bloody rain, and milk and butter were turned into blood" (Garmonsway 1972) and in AD 680 the Mozarabic chronicle also writes "that Spain was laid waste in that year" (Wolf 1999).

The period between AD 677 and AD 687 was also exceptionally arid in Central Europe. West Germany went through a drought in AD 679, 680 and 681. As a result, there was crop failure and a severe famine, the year AD 681 being the worst (Barash 1989). Thus, a vast geography (China, Spain, Germany and Britain) of climatic deviations may well mean that there could have been a global catastrophe on the planet at that time.

Anomalous climatic events of AD 680-685 are also confirmed by tree-ring data from North America, Europe, the Yamal and by ice-core results from the Antarctic and Greenland (Salzer and Hughes 2007; Gao et al. 2008; Plummer et al. 2012; Sigl et al. 2013, 2015; McKee et al. 2015).

Let's analyze the historical events of that period.

Regardless of the failures, in AD 682, the buck was taken up by the new leader of the Turks named Ashinagudulu who got together what was left of the Turks and created a 5000-strong army of mounted warriors. His first victory over the Chinese army took place in AD 682. In the years AD 683-685, under the leadership of Ashinagudulu, the Turks sacked quite a number of provinces and cities, killed a great number of local Chinese officials, and occupied the territory of a weakened tribe of nomads to the north of China. The said territory was practically a wasteland by that time. By AD 685, the Turks had the strongest army in the region. Nobody could withstand their attacks, even China, though it did undertake several unsuccessful attempts to defeat them.

Here we can trace a similarity with the events of AD 536-545. The Turks, as other nomads in the region, experienced all the hardships of life in the conditions of climatic cataclysms of AD 680-685. However, due to the predatory policy pursued by the northern provinces of China in AD 682-685, the Turks, not without losses of course, managed to overcome the heavy crisis, whereas the other nomadic tribes of Inner Asia were hit by the frost and died of starvation and disease, because they did not have any external source of food supply. As a result, the Turks turned out to be the strongest of all the other nomads in the region. Due to the successful military operations of Ashinagudulu in AD 682-685, China lost its military supremacy and the Turks had no need of China's protection anymore, so they became independent. 


\subsection{Conclusion}

The material presented here demonstrates that there is a definite interplay between the historical events and the climate extremes on the territory of Inner Asia, and that these events coincide with other climate anomalies in Europe and China.

It has been proved that such coincidences come parallel with the key events in the Turk Empire and with those in Northern China in the following years: AD 535-545 - the rise of the Turk Empire; AD 581-583 - the division of the Turk Empire into the Western and the Eastern Empires; AD 599-603-the strengthening of the Eastern Turks under the leadership of Qimin Qaghan; AD 627-630- the collapse of the Turk Empire; in AD 679-685-the second rise of the Turk Empire (Table 8.1).

Most climatologists believe that the reason for such phenomena is a large explosive volcanic eruption. It is quite possible that the center of the explosive volcanic eruption in AD 626 was in the Northern Hemisphere, and in AD 536, 581, 679 in the Southern Hemisphere, whereas in AD 536 and in AD 679, the eruption was supposedly caused by the Tavurvur volcano (Gao et al. 2008; McKee et al. 2015; Sigl et al. 2015).

In most cases, the climate extremes that are marked by tree-rings on fossils suggest that the global changes in the climate took place on a world-wide scale. The extremely sharp and protracted cooling on the territory to the east of Inner Asia affected this region more because it had a nomadic economy.

As is said in this thesis, it was the protracted droughts that led to the consequences that followed the natural catastrophes of this kind on the territory of the Turk Empire and in Northern China (AD 536, 581, 679). A case of an early and very long winter with heavy snowfalls was also recorded in AD 627-630, right after the eruption of a volcano in AD 626.

The most difficult times for the Turks were the years AD 627-630, when the Empire practically stopped existing due to massive loss of livestock and famine.

The droughts of AD 536, 581 and 679 turned out to be a serious trial for everyone in the region. Grazing vegetation dried up, forests and steppes blazed in fires.

However, Chinese sources tell us that during the droughts the Turks were in a better position than the Chinese. It happened at the time when the Turks took over the initiative from China to strengthen (in AD 545) and restore (in AD 682) their state. However, the drought led to serious consequences in China: the change of dynasties (AD 581) and the An Lushan Rebellion in AD 754.

In order to give a correct evaluation of the influence of the climatic extremes and its effects such as droughts, protracted cold and snowy winters on the territory to the east of Inner Asia, we must also take into account all the aspects of the political and socio-economic life in the region, so as to be able to give a correct evaluation of its influence on the Turkic and the Chinese population. The peculiar dynamics of the historical processes in that region were determined both by the climatic factors and by the complicated political situations.

Climate extremes were a prerequisite for changes in the military and political sphere in the region. They served as a background against which various socioeconomic and political events developed. However, they were not only a threat to the 
Table 8.1 Interplay of the historical facts and paleo-climatological data. As referential chronology we have used the most sensitive one for the given territory-Altai-LASI-ITRDB RUSS246 (Büntgen et al. 2016; Esper et al. 2016)

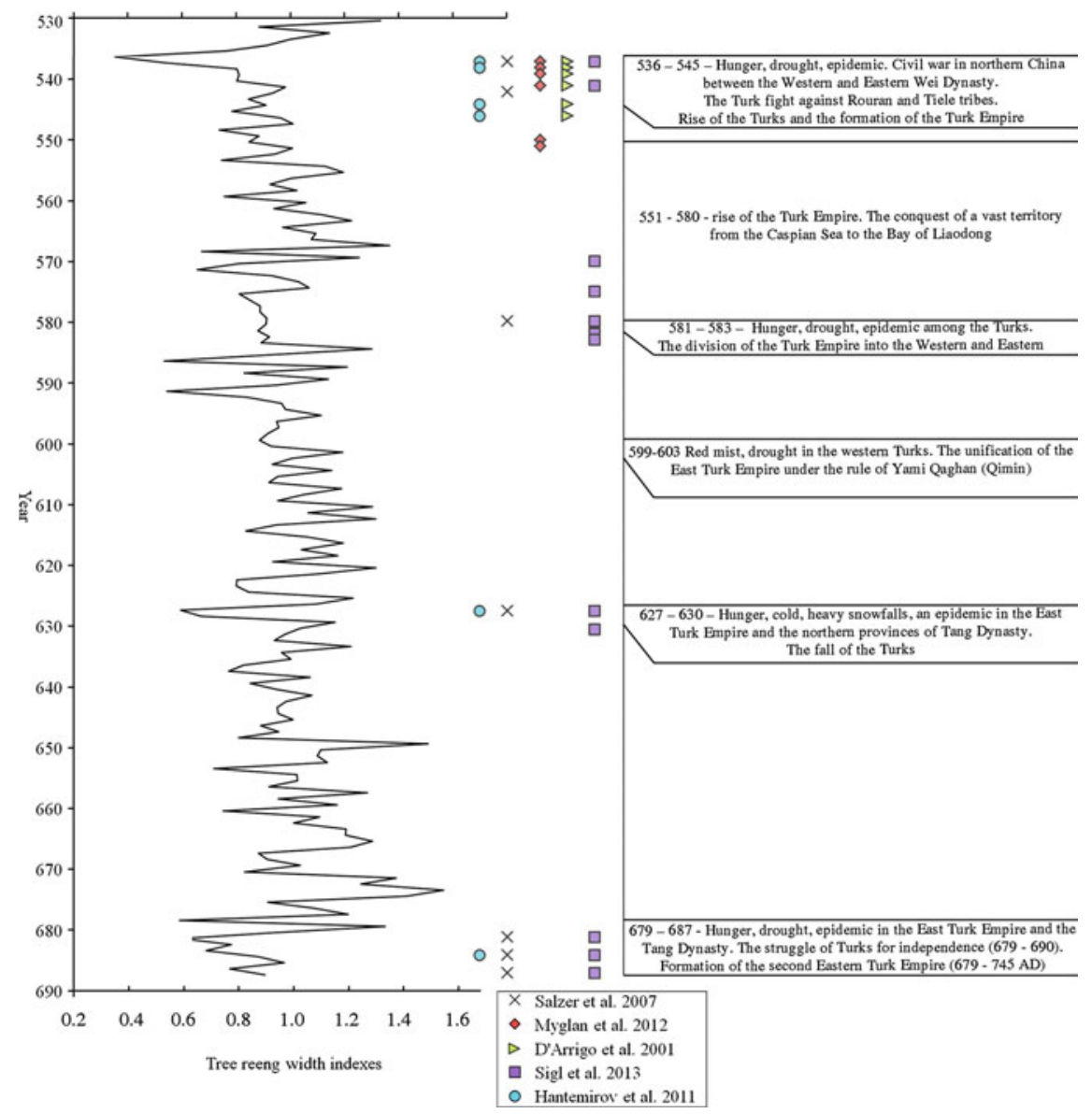

Standardized chronology_LASI (Büntgen et al. 2016)—on the left-hand side Anomalies in the structure of yearly rings-in the center Historical events in the Turk Empire taken from Chinese written sources—on the right-hand side

existence of the Turk Empire-they also provided certain advantages. Who was to use these advantages and how they were to be applied depended solely on the parties of the conflict and the circumstances they found themselves in. For example, in the case of the Turks - as with many other nomads of steppe Eurasia, a lot depended on the personality of the leader and his military skills.

Though much discussion is going on at present among researchers concerning the problem of the influence of climate changes on nomadic society, we hold to the opinion that the historical events that took place in the Turk Empire in AD 
534-551 and in AD 679-687 developed in a line parallel to the unfavorable changes in climate which may be considered as an additional factor that led to changes in the regional situation. Historical sources show that in the year AD 534 the Turks had already become stronger - a fact that happened prior to the climate extremes, but the discontent of the Turks with Emperor Gaozong's (AD 650-683) policy grew during the whole period of his reign and it is this that led to the rebellion of AD 679. Nevertheless, the sharp changes in the economic and political situation in the Turk Empire in AD 581-583, in AD 599-603 and in AD 627-630 totally coincide with the extreme changes in climate in these periods, a fact that may be looked upon as indirect proof of the interplay of historical processes in the region with climate dynamics.

Acknowledgements I would like to thank Dr. Rashid Hantemirov (Yekaterinburg, Russia) for the helpful and constructive comments and suggestions.

\section{References}

Abbott, D. H., Tester, E. W., Meyers, C. A., \& Breger, D. (2007). Impact ejecta and megatsunami deposits from a historical impact into the Gulf of Carpentaria. Geological Society of America Annual Meeting, Denver, CO. Abstracts with Programs, 39, 312.

Abbott, D. H., Breger, D., Biscaye, P. E., Robert, A. J. (2014). Calendar-year dating of the GISP2 ice core from the early 6th century using historical, ion and particulate data. In G. Keller \& A. Kerr (Eds.), Volcanism, impacts and mass extinctions: Causes and effects (pp. 411-420). Geological Society of America Special Paper, 505.

Baillie, M. G. L. (2008). Proposed re-dating of the European ice core chronology by seven years prior to the 7th century AD. Geophysical Reseach Letters, 35, 15.

Barash, S. I. (1989). Istoriya neurozhayev i pogody $v$ Yevrope [History of crop failure and weather in Europe] (pp. 236). Leningrad, Russia: Gidrometeoizdat.

Barfield, T. J. (1992). The Perilous frontier: Nomadic empires and China. 221 BC to 1757 AD (p. 348). Cambridge, United Kingdom: Wiley.

Beckwith, C. I. (2009). Empires of the Silk Road: A history of Central Eurasia from the bronze age to the present (p. 512). Princeton, USA: Princeton University Press.

Bichurin, N. Y. A. (1950). Sobraniye svedeniy o narodakh, obitavshikh v Sredney Azii v drevniye vremena [Collection of information about the peoples inhabiting Central Asia in ancient times] (pp. 382). T. I. Moscow-Leningrad, Russia: Izd-vo AS USSR.

Bichurin, N. Y. A. (Iakinf). (1828). Letopis' kitayskoy imperii, nazyvayemaya Yuy-p'khi tszy chzhi tkhun-tszyan' gan-mu. Razdelennaya na tri chasti, letopis' drevnyuyu, srednyuyu i noveyshuyu. Per. s kit. I. Bichurina [Chronicle of the Chinese Empire Zizhi Tongjian ganmu] T. VIII, f. 7, op. 1, yed. khr. 8. Arkhiv vostokovedov Sankt-Peterburgskogo Instituta vostochnykh rukopisey RAN.

Briffa, K. R., Melvin, T. M., Osborn, T. J., Hantemirov, R. M., Kirdyanov, A. V., Mazepa, V. S., et al. (2013). Reassessing the evidence for tree-growth and inferred temperature change during the Common Era in Yamalia, northwest Siberia. Quaternary Science Reviews, 72, 83-107.

Büntgen, U., Tegel, W., Nicolussi, K., McCormick, M., Frank, D., Trouet, V., et al. (2011). 2500 years of European climate variability and human susceptibility. Science, 331(6017), 578-582.

Büntgen, U., Myglan, V. S., Ljungqvist, F. C., McCormick, M., Di Cosmo, N., Sigl, M., et al. (2016). Cooling and societal change during the late antique little ice age from 536 to around $660 \mathrm{AD}$. Nature Geoscience, 9(3), 231-236.

Cen, Z. (1958). Tujue jishi (p. 1136). Beijing: Zhonghua shuju. 
Churakova-Sidorova, O. V., Bryukhanova, M. V., Saurer, M., Boettger, T., Naurzbaev, M. M., Myglan, V. S., et al. (2014). A cluster of stratospheric volcanic eruptions in the AD 530s recorded in Siberian tree rings. Global and Planetary Change, 122, 140-150.

Clausen, H. B., Hammer, C. U., Hvidberg, S., Dahl-Jensen, D., Steffensen, J. P., Kipfstuhl, J., et al. (1997). A comparison of the volcanic records over the past 4000 years from the Greenland Ice Core Project and Dye 3 Greenland ice cores. Journal Geophysical Research, 102(C12), 26707-26723.

Cole-Dai, J., Mosley-Thompson, E., Wight, S. P., \& Thompson, L. G. (2000). A 4100-year record of explosive volcanism from an East Antarctica ice core. Journal of Geophysical Research Atmospheres, 105(D19), 24431-24441.

D’Arrigo, R., Jacoby, G., Frank, D., Pederson, N., Cook, E., Buckley, B., et al. (2001). 1738 years of Mongolian temperature variability inferred from a tree-ring width chronology of Siberian pine. Geophysical Reseach Letters, 28(3), 543-546.

Di Cosmo, N., Oppenheimer, C., \& Büntgen, U. (2017). Interplay of environmental and sociopolitical factors in the downfall of the Eastern Turk Empire in 630 CE. Climate Change, 145(3-4), 383-395.

Drobyshev, Y. I. (2014). Chelovek i priroda v kochevykh obshchestvakh Tsentral'noy Azii [Man and nature in the nomadic societies of Central Asia] (p. 604). Moscow, Russia: IV RAS.

Durand, J. D. (1960). The population statistics of China, A.D. 2-1953. Population Studies: A Journal of Demography, 13(3), 209-256.

Ershisi shi. (2012). Beijing, China: Zhonghua shuju bian ji bu. http://www.weilishi.org/ershisishi. Accessed May 2, 2018.

Esper, J., Krusic, P. J., Ljungqvist, F. C., Luterbacher, J., Carrer, M., Cook, M., et al. (2016). Ranking of tree-ring based temperature reconstructions of the past millennium. Quaternary Science Reviews, 145, 134-151.

Fei, J., Zhou, J., \& An, Z. S. (2004). Temperature change in China over 618-959 AD: Based on historical records. Marine Geology and Quaternary Geology, 24(2), 109-118.

Fei, J., Zhou, J., \& Hou, Y. (2007). Circa A.D. 626 volcanic eruption, climatic cooling, and the collapse of the Eastern Turkic Empire. Climate Change, 81(3-4), 469-475.

Gao, C., Robock, A., \& Ammann, C. (2008). Volcanic forcing of climate over the past 1500 years: An improved ice core-based index for climate models. Journal of Geophysical Research Atmospheres, $113,23$.

Garmonsway, G. N. (1972). The Anglo-Saxon Chronicle (p. 371). London, United Kingdom: Everyman Press.

Gumilev, L. N. (1967). Drevniye tyurki [Ancient Turks] (pp. 504). Moscow, Russia: Nauka.

Hantemirov, R. M., Gorlanova, L. A., Surkov, A. Y., \& Shiyatov, S. G. (2011). Extreme climate events on Yamal for the last 4100 years according to dendrochronological data. Izvestiya Akademii Nauk. Seriya Geograficheskaya, 2, 89-102.

Hsiang, S. M., Burke, M., \& Miguel, E. (2013). Quantifying the influence of climate on human conflict. Science, 341(6151), 1235367.

Jiang, S., Cole-Dai, J., Li, Y., Ferris, D. G., Ma, H., An, C., et al. (2012). A detailed 2840 years record of explosive volcanism in a shallow ice core from Dome A, East Antarctica. Journal of Glaciology, 58(207), 65-75.

Jouzel, J. (2013). A brief history of ice core science over the last 50 yr. Climate Past, 9, 2525-2547.

Kamalov, A. (2001). The ancient Uyghurs in the 8-9 century (p. 216). Almaty, Kazakhstan: Nash mir.

Keys, D. P. (2000). Catastrophe: A quest for the origins of the modern world (p. 368). New-York, USA: Ballantine Books.

Klyashtorny, S. G. (1964). Drevnetyurkskiye runicheskiye pamyatniki kak istochnik po istorii Sredney Azii [Ancient Turkic runic monuments as a source on the history of Central Asia] (p. 214). Moscow, Russia: Nauka.

Kradin, N. N. (2014). Nomads of inner Asia in transition (p. 304). Moscow, Russia: URSS.

Larsen, L. B., Vinther, B. M., Briffa, K. R., Melvin, T. M., Clausen, H. B., Jones, P. D., SiggaardAndersen, M., Hammer, C. U., Eronen, M., Grudd, H., Gunnarson, B. E., Hantemirov, R. M., 
Naurzbaev, M. M., Nicolussi, K. (2008). New ice core evidence for a volcanic cause of the A.D. 536 dust veil. Geophysical Research Letters, 35(4).

Liu, M. T. (1958). Die chinesischen Nachrichten zur Geschichte der Ost-Turken (Tu-kue) [The Chinese news on the history of the Eastern Turks (Tu-kue)] (p. 831). Wiesbaden, Germany: Otto Harrassowitz Verlag.

Ludlow, F., Stine, A. R., Leahy, P., Murphy, E., Mayewski, P. A., Taylor, D., Killen, J., Baillie, M. G. L., Hennessy, M., Kiely, G. (2013). Medieval Irish chronicles reveal persistent volcanic forcing of severe winter cold events, 431-1649 CE. Environmental Research Letters, 8(2).

Mackerras, C. (2000). Uyghur-Tang Relations (744-840). Central Asian Survey, 19(2), 223-234.

McKee, C. O., Baillie, M. G., Reimer, P. J. (2015). A revised age of ad 667-699 for the latest major eruption at Rabaul. Bulletin of Volcanology, 77(7).

Myglan, V. S., Oidupaa, O. C., \& Vaganov, E. A. (2012). A 2367-year tree-ring chronology for the Altai-Sayan region (Mongun-Taiga mountain massif). Archaeology, Ethnology and Anthropology of Eurasia, 40(3), 76-83.

Pederson, N., Hessl, A. E., Baatarbileg, N., Anchukaitis, K. J., \& Di Cosmo, N. (2014). Pluvials, droughts, the Mongol Empire, and modern Mongolia. Proceedings of the National Academy of Sciences of the United States of America, 111(12), 4375-4379.

Plummer, C. T., Curran, M. A. J., van Ommen, T. D., Rasmussen, S. O., Moy, A. D., Vance, T. R., Clausen, H. B., Vinther, B. M., Mayewski, P. A. (2012). An independently dated 2000-yr volcanic record from Law Dome, East Antarctica, including a new perspective on the dating of the 1450s CE eruption of Kuwae, Vanuatu. Clim. Past. https://doi.org/10.5194/cp-8-1929-2012.

Procopius, C. (1998). The Persian War. The Vandalic War. The Secret History (p. 541). SaintPetersburg: Aleteya.

Putnam, A. E., Putnam, D. E., Andreu-Hayles, L., Cook, E. R., Palmer, J. G., Clark, E. H., et al. (2016). Little Ice Age wetting of interior Asian deserts and the rise of the Mongol Empire. Quaternary Science Reviews, 131, 33-50.

Rigby, E., Symonds, M., \& Ward-Thompson, D. (2004). A comet impact in AD 536? Astronomy and Geophysics, 45(1), 23-26.

Salzer, M. W., \& Hughes, M. K. (2007). Bristlecone pine tree rings and volcanic eruptions over the last 5000 yr. Quaternary Research, 67, 57-68.

Schmid, B. V., Büntgen, U., Easterday, W. R., Ginzler, C., Walløe, L., Bramanti, B., et al. (2015). Climate-driven introduction of the Black Death and successive plague reintroductions into Europe. Proceedings of the National Academy of Sciences of the United States of America, 112(10), 3020-3025.

Sigl, M., McConnell, J. R., Layman, L., Maselli, O., McGwire, K., Pasteris, D., et al. (2013). A new bipolar ice core record of volcanism from WAIS Divide and NEEM and implications for climate forcing of the last 2000 years. Journal of Geophysical Research Atmospheres, 118(3), 1151-1169.

Sigl, M., Winstrup, M., McConnell, J. R., Welten, K. C., Plunkett, G., Ludlow, F., et al. (2015). Timing and climate forcing of volcanic eruptions for the past 2,500 years. Nature, 523(7562), $543-549$.

Sinor, D. (1990a). The establishment and dissolution of the Türk empire: The Cambridge history of early inner Asia (pp. 285-316). Cambridge, United Kingdom and New York, USA: Cambridge University Press.

Sinor, D. (Ed.). (1990b). The Cambridge history of early inner Asia (pp. 581). Cambridge, United Kingdom and New York, USA: Cambridge University Press.

Southon, J., Mohtadi, M., \& De Pol-Holz, R. (2013). Planktonic foram dates from the Indonesian ARC: Marine $14 \mathrm{C}$ reservoir ages and a mythical AD 535 eruption of Krakatau. Radiocarbon, 55(2-3), 1164-1172.

Stavrakakis, N. (2015). The miraculous cures for diseases of Emperor Justinian I (482-565 AD). Archives of Hellenic Medicine, 32(2), 224-229.

Stothers, R. B. (1999). Volcanic dry fogs, climate cooling, and plague pandemics in Europe and the Middle East. Climate Change, 42(4), 713-723. 
Trenberth, K. E. (2012). Framing the way to relate climate extremes to climate change. Climate Change, 115(2), 283-290.

Wagner, D. M., Klunk, J., Harbeck, M., Devault, A., Waglechner, N., Sahl, J. W., et al. (2014). Yersinia pestis and the plague of Justinian 541-543 AD: A genomic analysis. Lancet. Infect. Dis, 14(4), 319-326.

Wei, Z., Rosen, A. M., Fang, X., Su, Y., \& Zhang, X. (2015). Macro-economic cycles related to climate change in dynastic China. Quaternary Research, 83(1), 13-23.

Wolf, K. B. (1999). Conquerors and Chroniclers of Early Medieval Spain (p. 205). Liverpool, United Kingdom: Liverpool University Press.

Zhang, D. D., Brecke, P., Lee, H. F., He, Y., \& Zhang, J. (2007). Global climate change, war, and population decline in recent human history. Proceedings of the National Academy of Sciences of the United States of America, 104(49), 19214-19219.

Zhang, Z., Tian, H., Cazelles, B., Kausrud, K. L., Bräuning, A., Guo, F., et al. (2010). Periodic climate cooling enhanced natural disasters and wars in China during AD 10-1900. Proceedings of the Royal Society B: Biological Sciences, 277(1701), 3745-3753.

Zhang, D. D., Lee, H. F., Wang, C., Li, B., Pei, Q., Zhang, J., et al. (2011). The causality analysis of climate change and large-scale human crisis. Proceedings of the National Academy of Sciences of the United States of America, 108(42), 17296-17301.

Open Access This chapter is licensed under the terms of the Creative Commons Attribution 4.0 International License (http://creativecommons.org/licenses/by/4.0/), which permits use, sharing, adaptation, distribution and reproduction in any medium or format, as long as you give appropriate credit to the original author(s) and the source, provide a link to the Creative Commons license and indicate if changes were made.

The images or other third party material in this chapter are included in the chapter's Creative Commons license, unless indicated otherwise in a credit line to the material. If material is not included in the chapter's Creative Commons license and your intended use is not permitted by statutory regulation or exceeds the permitted use, you will need to obtain permission directly from the copyright holder.

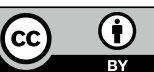

